\title{
Kepastian Hukum Perlindungan Pemegang Hak Desain Industri Bagi UMKM Di Indonesia
}

\author{
Afif Nashiruddin \\ Program Studi Magister Ilmu Hukum \\ Pascasarjana Universitas Islam Bandung \\ e-mail : nashiruddin.afif@gmail.com
}

\begin{abstract}
Abstrak - Peranan perlindungan desain industri sebagai salah satu bidang Hak Kekayaan Intelektual sering diabaikan apabila dibandingkan dengan perlindungan terhadap paten, merek atau hak cipta. Di Indonesia perkembangan industri di bidang kreatif sangat banyak, namun tidak didukung dengan perlindungan hukum yang sesuai. Perlindungan hukum diberikan agar desain industri yang dihasilkan pendesain tidak ditiru atau dimanfaatkan oleh pihak lain yang tidak berhak. Penelitian ini bertujuan untuk mengetahui dan memahami bentuk dan problematika serta model-model perlindungan terhadap pemegang hak desain industri UMKM di Indonesia. Penelitian ini menggunakan metode pendekatan yuridis normatif, dengan spesifikasi yaitu deskriptif analitis. Data yang digunakan adalah data sekunder yang diperoleh dari studi kepustakaan. Hasil dari penelitian ini menunjukkan bahwa agar desain industri dan merek dagang, dalam hal ini desain tekstil untuk desain motif batik dan merek dagang untuk produk batik, dapat dilindungi oleh hukum adalah dengan cara pendaftaran. Pendaftaran desain industri (desain tekstil untuk desain motif batik) menimbulkan hak eksklusif, yaitu hak khusus yang hanya diberikan oleh Negara untuk jangka waktu tertentu kepada Pemegang Hak Desain Industri untuk melaksanakan sendiri hak desain industri yang dimilikinya, atau memberikan persetujuan/izin kepada pihak lain untuk melaksanakan haknya atas desain tersebut.
\end{abstract}

\section{Kata Kunci : Hak Kekayaan Intelektual, Kepastian Hukum, Desain Industri}

\begin{abstract}
The role of industrial design protection as one of the fields of Intellectual Property Rights is frequently ignored if it is compared to the protection of patents, trademarks, or copyrights. In Indonesia, there are many industrial developments in the creative sector, but they are not supported by appropriate legal protection. Legal protection is given in order that the industrial design produced by the designer is not copied or exploited by other unauthorized parties. This study aimed at determining and understanding the forms, problems, and models of protection for micro, small, and medium enterprises (MSME) industrial design rights holders in Indonesia. This study used a normative juridical approach with a descriptive-analytical specification. The data used secondary data obtained from literature study. The result indicates that in order that industrial designs and trademarks, in this case textile designs for batik motif designs and trademarks for batik products, can be protected by law, the designers
\end{abstract}


must conduct registration. Registration of industrial designs (textile designs for batik motif designs) emerges exclusive rights, namely special rights granted only by the State for a certain period of time to Industrial Design Rights Holders to conduct their own industrial design rights or give approval/permission to other parties to conduct its rights to the design.

\section{Keywords: Intellectual Property Rights, Legal Certainty, Industrial Design}

\section{A. PENDAHULUAN}

Desain Industri adalah bagian dari Hak atas Kekayaan Intelektual. Perlindungan atas desain industri didasarkan pada konsep pemikiran bahwa lahirnya desain industri tak terlepas dari kemampuan kreativitas cipta, rasa dan karsa yang dimiliki oleh manusia. Jadi desain industri merupakan produk intelektual manusia, produk peradaban manusia.

Di Amerika dan Indonesia, HKI merupakan hak amanat aturan, sehingga masyarakatlah yang menentukan, seberapa besar HKI yang diberikan kepada individu dan kelompok. Akan tetapi di beberapa negara berkembang lainnya ada pemikiran bahwa justru perlindungan hak milik intelektual ini merupakan tembok penghalang bagi perkembangan ekonomi negara lebih lanjut. ${ }^{1}$

Hal ini dikarenakan anggapan bahwa HKI tidak lebih dari sebuah penjajahan model baru (neo kolonialisme). Dimana negara yang telah meratifikasi perjanjian Perdangangan Dunia (Agreement Establishing World Trade Organisation/ WTO), yang lebih khusus lagi berkait dengan perjanjian HaKI dalam Agreement on Trade Related Aspect of Intellectual Property Rights/ TRIPs menegaskan bahwa setiap negara yang telah ikut dalam organisasi perdagangan dunia harus menghormati keberadaan HKI. Sehubungan dengan hal ini, perlindungan HKI menimbulkan monopoli untuk negara yang sudah maju dan mengakibatkan suatu

1 Adrian Sutedi, Hak Atas Kekayaan Intelektual, Jakarta: Sinar Grafika, 2009, hlm. 23 
bentuk "persaingan yang tidak wajar" (unfair competition) terhadap negara-negara berkembang.

Indonesia berperan serta dalam kerja sama di bidang HKI dimulai sejak tahun 1950 diikuti dengan penandatanganan konvensi Paris pada tahun 1997. Selanjutnya Indonesia meratifikasi Agreement Establishing the World Trade Organization (WTO) atau Organisasi Perdagangan Dunia yang salah satu komponennya adalah TRIPs. Sebagai konsekuensinya Indonesia berkewajiban menaati semua ketentuan yang ada dalam konvensi internasional tersebut, Indonesia setuju untuk memenuhi kewajibannya berdasarkan TRIPs pada tahun $2000 .^{2}$

\section{Dalam Pasal 7 persetujuan} TRIPs disebutkan, bahwa perlindungan dan penegakan HKI bertujuan mendorong timbulnya inovasi, pengalihan dan penyebaran teknologi dan diperolehnya manfaat bersama antara penghasilan dan

${ }^{2}$ O. M. Febriani and A. S. Putra, "Sistem Informasi Monitoring Inventori Barang Pada Balai Riset Standardisasi Industri Bandar Lampung," J. Inform., vol. 13, no. 12014, hlm. 4 penggunaan teknologi, dengan cara menciptakan kesejahteraan sosial dan ekonomi serta keseimbangan antara hak dan kewajiban.

Desain Industri menurut pengertian Undang-Undang Nomor 31 Tahun 2000 tentang Desain Industri Pasal 1 angka 1 adalah: "Suatu kreasi tentang bentuk, konfigurasi, atau komposisi garis atau warna, atau garis dan warna, atau gabungan daripadanya yang berbentuk tiga dimensi atau dua dimensi yang memberikan kesan estetis dan dapat diwujudkan dalam pola tiga dimensi atau dua dimensi serta dapat dipakai untuk menghasilkan suatu produk, barang, atau komoditas industri, atau kerajinan tangan.”

Perlindungan hukum terhadap pemegang hak desain industri seringkali tidak berjalan sebagaimana maksud dan tujuan yang tertuang dalam UndangUndang, hal itu terjadi karena kurang adanya penguatan dan dukungan baik dari pemerintah serta masyarakatnya. Perlindungan hukum terhadap pemegang hak desain industri kurang mendapat perhatian yang maksimal 
dari pemerintah, dalam hal ini para penegak hukumnya. Oleh karena itu maka peran serta dari masyarakat sangat penting dalam rangka untuk mendukung serta melaksanakan kepastian hukum atas hak desain industri, baik subyek maupun obyeknya. Namun perkembangan prlindungan hukum terhadap pemegang hak desain industri pada saat ini masih jauh sebagaimana yang diharapkan, dimana masyarakat kelihatan skeptis dan kurang paham terhadap fungsi perlindungan hukum dari hak desain industri.

Hak desain industri merupakan hak milik eksklusif bagi pemegang haknya untuk mempertahankan, memonopoli dan menggunakan haknya. Pemegang hak desain industri mempunyai hak monopoli atau eksklusif, artinya dia dapat mempergunakan haknya dengan melarang siapapun tanpa persetujuannya membuat, memakai, menjual, mengimpor, mengekspor, dan/atau mengedarkan barang yang diberi hak desain industri, serta mempunyai kedudukan kuat sekali terhadap pihak lain. Apabila ada pihak yang melakukan pelanggaran terhadap haknya, dia dapat melakukan aksi hukum kepidanaan maupun keperdataan. ${ }^{3}$

Dalam praktek hukum, seringkali muncul ketidakpastian hukum dalam pelaksanaan hak desain industri, terutama bagi pelaku UMKM. Hal tersebut terjadi karena ada kepentingan bisnis diantara para pelaku bisnis, yang dilakukan dengan cara meniru atau menggunakan "kesamaan atau kemiripan" suatu desain industri yang telah ada sertifikat desain industri, disamping memang pemerintah kurang maksimal dalam mewujudkan perlindungan hukum terhadap pemegang hak desain industri. Oleh karena itu maka pada akhirnya telah menimbulkan ketidakpastian terhadap pelaksanaan hak desain industri itu sendiri. Hal itu terlihat semacam ada pembiaran pemerintah di tengah-tengah maraknya persaingan bisnis, apalagi saat ini begitu banyak produk-produk asing telah berada di pasaran domestik.

\footnotetext{
Muhammad Djumhana dan R.Djubaedillah, Hak Milik Intelektual (Sejarah, teori dan prakteknya di Indonesia), Edisi Revisi, Cetakan Ketiga (Bandung : PT. Cipta Aditya Bakti, 2003), hlm 242.
} 
Pemerintah seperti membiarkan adanya beberapa desain industri yang sama atau minimal mirip di tengah pasaran domestik, entah alasan dari pemerintah apa? Tetapi dengan adanya pembiaran dari pemerintah seperti tersebut diatas maka di pasaran domestik begitu banyak pelanggaran desain industri yang dapat kita jumpai, hal tersebut dapat membuat masyarakat terkecoh pada bentuk, konfigurasi dan komposisi warna dan garis pada suatu produk yang sama atau minimal mirip tersebut, namun dijual dengan harga yang murah, tetapi dari sisi kualitas mungkin ada perbedaan dengan produk yang telah ada sertifikat desain industrinya. Hal ini jika dibiarkan, akan sangat merugikan masyarakat, masyarakat secara perlahan-lahan telah ditipu oleh pelaku bisnis, dengan cara meniru atau menjiplak suatu produk, demi kepentingan bisnis semata-mata. Namun anehnya masyarakat kita terlihat pasif melihat fenomena pasar seperti itu, masyarakat seperti diam dengan membiarkan pelanggaran hak desain industri merajalela di tengah pasar domestik, sehingga penegakan hukum terhadap hak desain industri untuk mewujudkan kepastian hukum dan perlindungan hukum terhadap kepentingan masyarakat belum berjalan dengan maksimal.

Permasalahan pelaksanaan hak desain industri bagi pelaku UMKM ada beberapa hal, hak desain industri telah nyata belum mampu untuk melindungi kepentingan pemegang hak eksklusifnya, hal tersebut disebabkan karena beberapa faktor, diantaranya adalah adanya konflik kepentingan politik

\section{B. RUMUSAN MASLAH}

1. Bagaimana bentuk perlindungan pemegang hak desain industri bagi UMKM di Indonesia?

2. Bagaimana perlindungan pemegang hak desain industri bagi UMKM di Indonesia?

3. Bagaimana model ideal perlindungan pemegang hak desain industri bagi UMKM di Indonesia?

\section{PEMBAHASAN}

1. Bentuk perlindungan pemegang hak desain industri bagi UMKM di Indonesia 
Perlunya aturan hukum dalam bentuk Undang-undang yang mengatur mengenai desain industri dan merek dimaksudkan untuk memberikan perlindungan hukum yang tegas, jelas, dan efektif guna mencegah berbagai bentuk pelanggaran, yang dilakukan oleh orang yang tidak berhak, berupa peniruan dan pemalsuan. Di samping itu juga perlindungan hukum desain industri dan merek ini dimaksudkan untuk menjamin hak-hak serta kewajiban-kewajiban pendesain dan pemilik merek.

Pasal 6, 7, dan 8 UU No. 31/2000 tentang Desain Industri mengatur secara tegas mengenai subjek desain industri. Pasal 6 ayat (1) menyatakan bahwa "yang berhak memperoleh hak desain industri adalah Pendesain atau yang menerima hak tersebut dari Pendesain". Sedangkan ayat (2) nya menyatakan bahwa "dalam hal Pendesain terdiri atas beberapa orang secara bersama maka hak desain industri diberikan kepada mereka secara bersama, kecuali diperjanjikan lain".
Pendesain dapat diartikan sebagai subjek hukum, baik secara perorangan atau dalam ikatan kelompok, yang menghasilkan/melahirkan suatu karya desain yang bersifat khas dan dijadikan suatu "pattern" dalam kegiatan produksi pada dunia industri. Sedangkan Pemegang Hak Desain adalah Pendesain sebagai Pemilik Desain atau orang yang menerima hak atas desain tersebut dari Pendesain, atau orang lain yang menerima lebih lanjut hak termaksud dari orang-orang yang terlebih dahulu.

Desain industri merupakan salah satu bagian HAKI yang unik dan memerlukan suatu persamaan persepsi, mengingat adanya tumpang tindih antara desain industri dan bagian HAKI lainnya. Selain itu, terdapat beberapa konsep hukum mengenai bagian HAKI lainnya seperti paten dan hak cipta yang juga digunakan dalam desain industri. Dari hukum paten mengambil jangka waktu monopoli yang terbatas yang didapat melalui pendaftaran yang memberikan hak kepada pemilik/pemegang hak atas desain 
untuk menghentikan pihak lain utuk memproduksi produk dengan desain yang sama, dan konsep kebaharuan atas desain merupakan syarat mutlak agar suatu desain dapat didaftarkan. Sedangkan dari hukum hak cipta, desain industri meminjam konsep ide-ide menjadi bentuk-bentuk fisik yang merupakan perwujudan dari ide $^{4}$.

Pasal 1 butir 1 UU No. 31 Tahun 2000 tentang Desain Industri merumuskan pengertian desain industri sebagai :

"Desain industri adalah suatu kreasi tentang bentuk, konfigurasi, atau komposisi garis atau warna, atau garis dan warna, atau gabungan daripadanya yang berbentuk tiga dimensi atau dua dimensi yang memberikan kesan estetis dan dapat diwujudkan dalam pola tiga dimensi atau dua dimensi yang memberikan kesan estetis serta dapat untuk menghasilkan suatu produk,

${ }^{4}$ Ranti Fauza Mayana, Pelindungan Desain Industri di Indonesia dalam era Perdagangan Bebas, (Jakarta : Grasindo, 2004), hal. 48. barang, komoditas industri, atau kerajinan tangan."

Berdasarkan definisi tersebut, dapat disimpulkan dalam desain industri juga meliputi pola untuk untuk barang kerajinan, termasuk kerajinan tangan yang dalam hal ini adalah karya batik, selain barang industri. Jadi pada dasarnya desain industri merupakan "pattern" yang dipakai dalam proses produksi barang secara komersil dan dipakai secara berulang-ulang. Unsur dipakainya dalam proses produksi yang berulang-ulang inilah yang merupakan ciri dan bahkan pembeda dari ciptaan yang diatur dalam hak cipta. $^{5}$

Sedangan pengertian desain dapat diartikan sebagai bidang ketrampilan, pengetahuan, dan pengalaman manusia yang mencerminkan keterikatannya dengan apresiasi dan adaptasi lingkungannya ditinjau dari kebutuhan-kebutuhan kerohanian, komposisi, arti, nilai dan tujuan dari fenomena buatan manusia. Dari pengertian desain tersebut dapat

${ }^{5}$ Ibid., hal.51. 
terlihat ruang lingkup desain, yaitu mencakup pembuatan peralatan sehari-hari dari yang paling kecil seperti sendok garpu hingga pada corak dan model tekstil serta pakaian, perumahan hingga tata kota beserta alat-alat transportasi beserta jaringannya. Oleh karena itu secara luas bidang desain mencakup bidang desain produk, tekstil, interior, grafis, arsitektur, desain rekayasa serta desain kota yang semuanya itu dibuat dalam rangka pemenuhan kebutuhan spiritual dan material manusia ${ }^{6}$. Kebutuhan perlindungan desain Industri dalam UMKM harus ditempatkan dala salah satu prioritas utama karena pelaku UMKM yang rata-rata pengusaha dengan modal kecil sangat rawan untuk dimanfaatkan atau dilakukan penggaran HKI bagi pemilik modal besar yang mempunyai jaringan untuk dapat mengklaim suatu bentuk desain industri.

\footnotetext{
${ }^{6}$ Yustiono, Paradigma Desain Indonesia, Paradigma Desain Indonesia, ed. Agus Sachari, (Jakarta : Rajawali, 1986), hal.23, Lihat juga Muhammad Djumhana, AspekAspek Hukum Desain Industri di Indonesia, (Bandung : PT. Citra Aditya Bakti, 1999), hal. 5 .
}

Bicara mengenai desain, ada 4 (empat) disiplin utama desain, yaitu desain industri, desain interior, desain komunikasi visual (grafis), dan desain tekstil. Untuk desaindesain batik masuk dalam desain tekstil. Desain tekstil sangat kental hubungannya dengan citra, gaya hidup dan kecantikan, namun dalam dunia tradisional juga tidak terlepas dari nilai keagamaan dan adat. Ruang lingkup desain tekstil menyangkut kegiatan manusia dalam menjawab kebutuhan dan memenuhi kebutuhan akan sandang dalam arti yang luas. Dalam proses, menyangkut soal bentuk, desain tekstil terbagi atas desain struktur dan permukaan ${ }^{7}$.

Desain tekstil yang menyangkut bentuk desain struktur kebanyakan terdapat pada kain ikat tradisional, sedangkan desain tekstil yang menyangkut bentuk desain permukaan kebanyakan terdapat pada batik. Desain tekstil, baik untuk bentuk desain struktur pada kain ikat maupun untuk bentuk desain permukaan pada batik, umumnya mempunyai pola tertentu yang telah baku dan telah dijadikan patokan

${ }^{7} \mathrm{Ibid}$. 
untuk desain-desain selanjutnya, Pada dasarnya, desain struktur dan permukaan pada tekstil berkisar pada hiasan geometris, hiasan manusia, hiasan tumbuh-tumbuhan, hiasan binatang, dan hiasan bentuk-bentuk gejala alam.

Selain aspek bidang desain industri, khususnya desain tekstil, dalam industri batik juga menyangkut aspek bidang merek dagang. Hal ini karena produk batik yang diproduksi, baik dalam bentuk kain, selendang maupun baju, akan dipasarkan atau diperdagangkan ke masyarakat dengan menggunakan merek dagang yang menjadi simbol dari masing-masing perusahaan yang bersangkutan.

Oleh karena itu dalam dunia industri, termasuk dalam hal ini industri batik, merek mempunyai peran yang sangat penting, karena merek dapat berfungsi sebagai tanda pengenal untuk membedakan produk perusahaan yang satu dengan produk perusahaan yang lain yang sejenis serta menghubungkan produk dengan produsen/pedagangnya sebagai jaminan reputasi hasil usahanya ketika diperdagangkan. Merek juga berfungsi sebagai sarana promosi dagang, dimana merek merupakan simbol pengusaha untuk memperluas pasar produk dagangnya serta untuk menarik minat konsumen untuk membeli, sebagai jaminan atas mutu produk karena melalui merek konsumen dapat mengetahui akan mutu produk yang dibelinya, dan juga sebagai asal produk dimana merek merupakan tanda pengenal asal produk yang menghubungkan produk dengan produsen atau dengan daerah/Negara asalnya ${ }^{8}$.

Pasal 1 butir 1 UU No. 15 Tahun 2001 tentang Merek memberikan definisi merek sebagai suatu tanda yang berupa gambar, nama, kata, huruf-huruf, angkaangka, susunan warna, atau kombinasi dari unsur-unsur tersebut yang memiliki daya pembeda dan digunakan dalam kegiatan perdagangan barang dan jasa. Sedangkan Pasal 1 butir 2 nya mengartikan merek dagang sebagai suatu merek yang digunakan pada barang yang diperdagangkan oleh

\footnotetext{
8 Abdulkadir Muhammad, Kajian Hukum Ekonomi Hak Kekayaan Intelektual, (Bandung : PT Citra Aditya Bakti, 2001), hal. 120.
} 
seseorang atau beberapa orang secara bersama-sama atau badan hukum untuk membedakan dengan barangbarang sejenisnya.

\section{Perlindungan Pemegang Hak} Desain Industri Bagi UMKM di

\section{Indonesia}

Perlindungan hukum terhadap HKI mengalami perkembangan yang sangat pesat dalam tatanan internasional dan bahkan menjadi salah satu isu pada era globalisasi skrng ini. Kususnya sejak disepakatinya perjanjian internasional tentang aspek-aspek hak kekayaan intelektual dalam perdagangan (trade related aspects of intellectual property rights) yang merupakan menjadi bagian tidak terpisahkan dari perjanjian tentang pendirian World Trade Organization (WTO) yang telah diratifikasi oleh 150 lebih Negara di dunia. Perjanjian ini mengukuhkan penegakan hukum (law enforcement) yang lebih ketat dan memperluas ruang lingkup perlindungan HKI dari perjanjian internasional sebelumnya yang diprakarsai oleh World Intellectual Property Organization (WIPO), seperti Bern Convention, Paris convention, Roma Convention dan Washington treaty. ${ }^{9}$

Prinsip-prinsip Umum Hak Kekayaan Intelektual: ${ }^{10}$

a. Prinsip HKI sebagai hak eksklusif

Perlindungan terhadap hak kekayaan intelektual pada dasarnya berintikan pengakuan hak atas kekayaan tersebut dan hak untuk jangka waktu tertentu menikmati ataupun menggunakan, mengeksploitasi hak tersebut tanpa ijinnya.

b. Prinsip melindungi HKI berdasarkan pendaftarannya

1. First To File System, berdasarkan pada pendaftaran pertama. Artinya jika ada dua orang yang mendaftarkan kekayaan intelektual pada hari yang sama, pihak yang mendaftar terlebuh dahululah yang diprioritaskan untuk diproses.

\footnotetext{
${ }^{9}$ Ibid, hlm. 9

10 Djumhana Muhammad, perkembangan Doktrin dan Teori Perlindungan Hak Kekayaan Intelektual, PT. Citra Aditya Bkti, 2006, Hlm. 16
} 
2. First To Use System, berdasarkan pada penggunaan pertam, artinya pemilik kekayaan intelektual yang akan didaftar adalah orang yang pertama menggunakan kekayaan intelektual tersebut.

3. Prinsip perlindungan KI bersifat terbatas, meskipun ada cabang KI (merk) yang dapat diperpanjang jangka waktu perlindungannya, secara umum jangka waktu perlindungan KI tidak selamanya atau bersifat terbatas. Tujuan pembatasan perlindungan ini adalah untuk memberikan kesempatan kepada masyarakat untuk mengakses kekayaan intelektual tersebut secara optimal melalui usaha-usaha pengembangan lebih lanjut dan sekaligus mencegah monopoli atas kekayaan intelektual tersebut.

4. Prinsip KI yang berakhir jangka waktu perlindungannya berubah menjadi Public Domain, KI yang telah berakhir jangka waktu perlindungannya akan menjadi milik umum (public domain). Ini artinya semua orang berhak untuk mengakses KI yang telah berakhir jangka waktu perlindungannya.

5. Prinsip ekonomi Prinsip ekonomi, yakni hak intelektual berasal dari kegiatan kreatif suatu kemauan daya pikir manusia yang diekspresikan dalam berbagai bentuk yang akan memeberikan 
keuntungan kepada

pemilik

yang

bersangkutan.

6. Prinsip Keadilan.

Prinsip keadilan,

yakni di dalam

menciptakan sebuah

karya atau orang yang

bekerja membuahkan

suatu hasil dari

kemampuan

intelektual dalam ilmu

pengetahuan, seni, dan

sastra yang akan

mendapat

perlindungan dalam

pemiliknya. Prinsip

Kebudayaan. Prinsip

kebudayaan, yakni

perkembangan ilmu

pengetahuan, sastra,

dan seni untuk

meningkatkan

kehidupan manusia

7. Prinsip Sosial. Prinsip sosial ( mengatur kepentingan manusia sebagai warga Negara ), artinya hak yang diakui oleh hukum dan telah diberikan kepada individu

merupakan satu

kesatuan sehingga

perlindungan

diberikan berdasarkan

keseimbangan

kepentingan individu

dan masyarakat.

Berdasarkan WIPO hak atas kekayaan intelaktual dapat dibagi menjadi dua bagian, yaitu hak cipta (copyright), dan hak kekayaan industri (industrial property right). Hak kekayaan industry ( industrial property right ) adalah hak yang mengatur segala sesuatu tentang milik perindustrian, terutama yang mengatur perlindungan hukum. Hak kekayaan industry ( industrial property right ) berdasarkan pasal 1 Konvensi Paris mengenai perlindungan Hak Kekayaan Industri Tahun 1883 yang telah di amandemen pada tanggal 2 Oktober 1979, meliputi :

1. Paten

2. Merek

3. Varietas tanaman

4. Rahasia dagang

5. Desain industry 
6. Desain tata letak sirkuit terpadu

Dasar hukum Hak Kekayaan Intelektual :

1. UU Nomor 19 Tahun 2002 tentang Hak Cipta

2. UU Nomor 6 Tahun 1982 tentang Hak Cipta (Lembaran Negara RI Tahun 1982 Nomor 15)

3. UU Nomor 7 Tahun 1987 tentang Perubahan atas UU Nomor 6 Tahun 1982 tentang Hak Cipta (Lembaran Negara RI Tahun 1987 Nomor 42)

4. UU Nomor 12 Tahun 1997 tentang Perubahan atas UU Nomor 6 Tahun 1982 sebagaimana telah diubah dengan UU Nomor 7 Tahun 1987 (Lembaran Negara RI Tahun 1997 Nomor 29)

5. Undang-undang Nomor 19 Tahun 2002 Tentang Hak Cipta.

6. Undang-Undang Nomor 28 Tahun 2014 Tentang Hak Cipta.

Hak Cipta adalah hak khusus bagi pencipta untuk mengumumkan atau memperbanyak ciptaannya.
Termasuk ciptaan yang dilindungi adalah ciptaan dalam bidang ilmu pengetahuan, sastra dan seni. Berdasarkan Undang-Undang Nomor 19 Tahun 2002 Tentang Hak Cipta: Hak Cipta adalah hak eksklusif bagi Pencipta atau penerima hak untuk mengumumkan atau memperbanyak Ciptaannya atau memberikan izin untuk itu dengan tidak mengurangi pembatasan-pembatasan menurut peraturan perundang-undangan yang berlaku.

Perlunya aturan hukum dalam bentuk Undang-undang yang mengatur mengenai desain industri dan merek dimaksudkan untuk memberikan perlindungan hukum yang tegas, jelas, dan efektif guna mencegah berbagai bentuk pelanggaran, yang dilakukan oleh orang yang tidak berhak, berupa peniruan dan pemalsuan. Di samping itu juga perlindungan hukum desain industri dan merek ini dimaksudkan untuk menjamin hak-hak serta kewajibankewajiban pendesain dan pemilik merek.

Batik, sebagai produk nasional yang menjadi kebanggaan bangsa Indonesia, memiliki beragam 
desain motif batik yang menjadi ciri khas dari asal daerah yang bersangkutan. Oleh karena desain motif batik dan merek dagang dari produk batik merupakan kekayaan intelektual, maka sudah seharusnya mendapatkan perlindungan hukum. Perlindungan hukum terhadap desain tekstil untuk desain motif batik, akan merangsang aktifitas kreatif pendesain untuk terus menerus berkarya dalam menciptakan desaindesain motif batik yang baru maupun desain-desain baju batik yang baru yang dapat menjadi "trend" dikalangan masyarakat luas. Sedangkan perlindungan hukum terhadap merek dagang produk batik akan memberikan kepastian hukum bagi perusahaan sebagai pemilik merek dalam penggunaan merek dagangnya untuk produk batik yang diproduksi maupun dipasarkan ke masyarakat. Dengan adanya kepastian hukum ini, maka mencegah orang lain yang tidak berhak untuk memakai merek yang sama pada pokoknya atau pada keseluruhan dengan merek dagang produk batik dari si pemilik merek yang sah. Selain itu juga mencegah orang lain yang tidak berhak untuk memakai/menggunakan/membuat/me njual desain orang lain yang bukan miliknya.

Pasal 6, 7, dan 8 UU No. 31/2000 tentang Desain Industri mengatur secara tegas mengenai subjek desain industri. Pasal 6 ayat (1) menyatakan bahwa "yang berhak memperoleh hak desain industri adalah Pendesain atau yang menerima hak tersebut dari Pendesain". Sedangkan ayat (2) nya menyatakan bahwa "dalam hal Pendesain terdiri atas beberapa orang secara bersama maka hak desain industri diberikan kepada mereka secara bersama, kecuali diperjanjikan lain”. Lebih jauh Pasal 7 ayat (1) UU No. 31/2000 tentang Desain Industri menyatakan bahwa "jika suatu desain industri dibuat dalam hubungan dinas dengan pihak lain dalam lingkungan pekerjaannya, yang menjadi Pemegang Hak Desain Industri adalah pihak yang untuk dan/atau dalam dinasnya desain industri itu dikerjakan, kecuali ada perjanjian lain antara kedua pihak dengan tidak mengurangi hak Pendesain apabila penggunaan 
desain industri diperluas sampai ke luar hubungan dinas". Ayat (2) menyatakan bahwa " ketentuanketentuan sebagaimana dimaksud dalam ayat (1) berlaku pula bagi desain industri yang dibuat orang lain berdasarkan pesanan yang dilakukan dalam hubungan dinas". Dan ayat (3) nya menyatakan bahwa “jika suatu desain industri dibuat dalam hubungan kerja atas berdasarkan pesanan, orang yang membuat desain industri itu dianggap sebagai Pendesain dan Pemegang Hak Desain Industri, kecuali jika diperjanjikan lain antara kedua pihak". Berdasarkan ketentuan Pasal 8 UU No. 31/2000 tentang Desain Industri, Pendesain tetap mempunyai hak untuk tetap dicantumkan namanya dalam Sertifikat Desain Industri, Daftar Umum Desain Industri dan Berita Resmi Industri.

Pendesain dapat diartikan sebagai subjek hukum, baik secara perorangan atau dalam ikatan kelompok, yang menghasilkan/melahirkan suatu karya desain yang bersifat khas dan dijadikan suatu "pattern" dalam kegiatan produksi pada dunia industri. Sedangkan Pemegang Hak Desain adalah Pendesain sebagai Pemilik Desain atau orang yang menerima hak atas desain tersebut dari Pendesain, atau orang lain yang menerima lebih lanjut hak termaksud dari orang-orang yang terlebih dahulu. $^{11}$

Dalam kondisi yang umum, Pendesain melakukan kegiatannya secara mandiri tidak terikat dalam hubungan hukum dengan pihak lain, misalnya dalam ikatan kerja atau perburuhan, maka secara mudah dapat ditentukan bahwa pihak yang menjadi Pemegang Hak dan sekaligus Pemilik Hak atas Desain adalah Pendesain itu Sendiri. Namun dalam hal Pendesain menjalankan kegiatannya terikat dalam hubungan hukum dengan pihak lain, terdapat ketentuan tertentu mengenai subjek hukum desain industri sebagai berikut $:^{12}$

a. Jika suatu desain dibuat dalam hubungan dinas atau hubungan kerja, pihak yang berhak memperoleh hak desain adalah pihak yang

11 Ibid., hal.43. Lihat juga Ranti Fauza Mayana, Op.Cit., hal.57.

${ }^{12}$ Ibid., hal 44. 


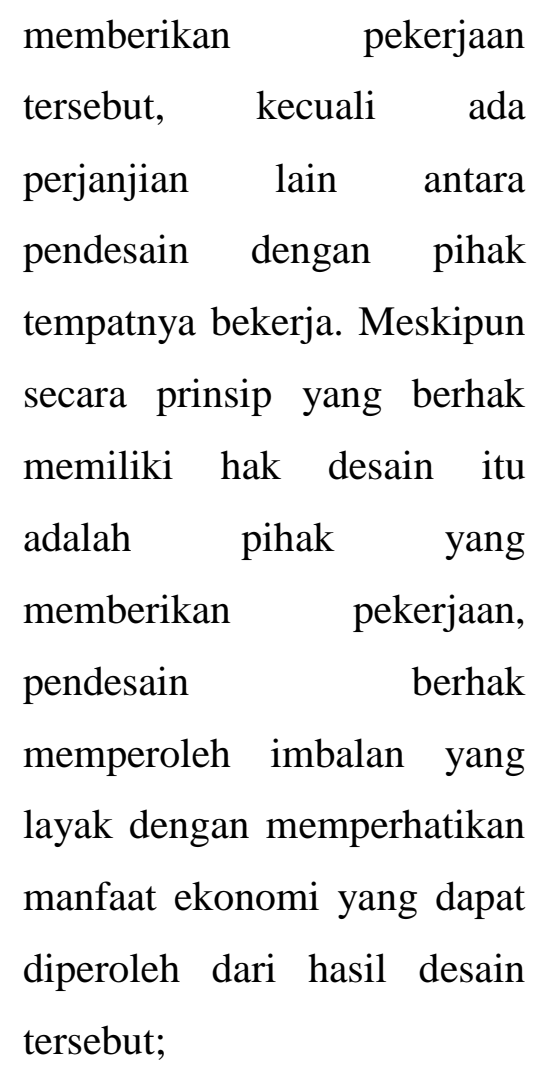

b. Jika suatu desain dibuat berdasarkan pesanan, pihak yang membuat desain itu sebagai pendesainnya dan sebaliknya pemilik desain itu sebagai pemesannya, kecuali apabila diperjanjikan lain antara kedua pihak tersebut;

c. Desain yang dihasilkan baik oleh karyawan maupun pekerja yang menggunakan data dan sarana yang tersedia dalam pekerjaannya, pemiliki desain tersebut adalah pihak tempat karyawan/pekerja tersebut bekerja, sekalipun perjanjian kerja itu mengharuskannya untuk menghasilkan desain.

Dengan demikian, meskipun pendesain tidak mempunyai hak atas desain tersebut, pendesain tetap berhak memperoleh kompensasi karena adanya nilai ekonomi yang diperoleh dari desain tersebut.

Dengan demikian, Pemegang Hak Desain Indusrtri adalah Pendesain, atau Penerima hak dari Pendesain karena pewarisan atau pengalihan atau sebab-sebab lain yang dibenarkan Undang-undang, atau Pemberi kerja dalam hubungan dinas, atau Pembuat sebagai Pendesain dalam hubungan kerja, yang namanya tercatat dalam Daftar Umum Desain Industri. Jadi dasar yuridis untuk mengetahui siapa Pemegang Hak Desain Industri yang sah adalah Daftar Umum Desain Industri, dimana namanya terdaftar dan telah diumumkan secara resmi dalam Berita Resmi Desain Industri.

Oleh karena cakupan desain industri sangat luas serta keterkaitannya dengan disiplin yang lain, maka ada beberapa pihak yang 
terlibat dalam konsep desain industri, yaitu Desainer sebagai orang yang merancang, Manufaktur yang membuat produk, Pemakai produk (konsumen/masyarakat), Lembaga Swadaya Masyarakat terutama di bidang konsumen dan lingkungan hidup, dan Pemerintah.

Dalam bidang merek, pemilik merek adalah seseorang, beberapa orang secara bersama-sama atau badan hukum yang telah menciptakan suatu tanda yang digunakan sebagai merek untuk produk yang mereka produksi dan/atau perdagangkan, yang mana merek tersebut sudah terdaftar dalam Daftar Umum Merek. Jadi Pemegang Hak atas Merek adalah Pemilik Merek itu sendiri atau orang lain yang mendapat hak atas merek dari si Pemilik Merek berdasarkan perjanjian (lisensi) ${ }^{13}$.

13 UU No.15/2001 tentang Merek tidak mengatur secara tegas pengertian Pemilik Merek. Namun secara implisit hal tersebut dalam dilihat dari isi Pasal 3 UU No.15/2001 tentang Merek beserta Penjelasannya. Pasal 3 menyatakan bahwa "Hak atas Merek adalah hak eksklusif yang diberikan oleh Negara kepada Pemilik Merek yang terdaftar dalam Daftar Umum Merek untuk jangka waktu tertentu dengan menggunakan sendiri Merek tersebut atau memberikan izin kepada pihak lain untuk menggunakannya."
Agar desain industri dan merek dagang, dalam hal ini desain tekstil untuk desain motif batik dan merek dagang untuk produk Batik, dapat dilindungi hukum adalah dengan cara pendaftaran. Pendaftaran desain industri (desain tekstil untuk desain motif batik) menimbulkan hak eksklusif, yaitu hak khusus yang hanya diberikan oleh Negara untuk jangka waktu tertentu kepada Pemegang Hak Desain Industri untuk melaksanakan sendiri hak desain industri yang dimilikinya, atau memberikan persetujuan/izin kepada pihak lain untuk melaksanakan haknya atas desain tersebut.

Dengan demikian orang lain yang tidak berhak dilarang menggunakan/membuat/memakai/me njual desain industri tersebut tanpa persetujuan dari Pemegang Hak Desain Industri ${ }^{14}$. Pemegang Hak Desain Industri memberikan persetujuan (izin) kepada pihak lain untuk melaksanakan (menggunakan) haknya atas desain tersebut dapat melalui pewarisan, hibah, wasiat, perjanjian tertulis, atau sebab-sebab

\footnotetext{
${ }^{14}$ Pasal 9 ayat (1) UU No. 31 Tahun 2001 tentang Desain Industri.
} 
lain yang dibenarkan oleh Undangundang ${ }^{15}$. Hal yang sama berlaku juga untuk merek dagang produk batik. Pendaftaran merek (merek dagang produk batik) menimbulkan hak eksklusif, yaitu hak khusus yang hanya diberikan oleh Negara kepada bagi Pemilik Merek yang terdaftar dalam Daftar Umum Merek untuk jangka waktu tertentu menggunakan sendiri merek tersebut atau memberikan persetujuan (izin) kepada pihak lain untuk menggunakannya ${ }^{16}$. Pemilik Merek yang terdaftar dalam Daftar Umum Merek dapat memberikan persetujuan (izin) kepada pihak lain untuk menggunakan mereknya melalui pewarisan, hibah, wasiat, perjanjian tertulis, atau sebab-sebab lain yang dibenarkan oleh Undangundang $^{17}$.

Jadi hak desain industri tercipta karena pendaftaran dan hak eksklusif atas suatu desain akan diperoleh karena pendaftaran. Pendaftaran adalah mutlak untuk

\footnotetext{
${ }^{15}$ Pasal 31 UU No. 31 Tahun 2000 tentang Desain Industri.

${ }^{16}$ Pasal 3 UU No. 15 Tahun 2001 tentang Merek.

${ }^{17}$ Pasal 40 UU No. 15 Tahun 2001 tentang Merek.
}

terjadinya suatu hak desain industri. Tanpa pendaftaran, tidak akan ada hak atas desain industri, juga tidak akan ada perlindungan hukum. Hal yang sama berlaku juga pada merek. Hak atas merek tercipta karena pendaftaran pertama kali atas merek tersebut dan hak eksklusif atas merek akan diperoleh karena pendaftaran pertama kali atas merek tersebut. Tanpa pendaftaran, tidak akan ada hak atas merek, juga tidak akan ada perlindungan hukum atas merek tersebut. Hal ini secara tegas diatur dalam Pasal 12 UU No. 31 Tahun 2000 tentang Desain Industri yang menyatakan bahwa "Pihak yang untuk pertama kali mengajukan Permohonan dianggap sebagai Pemegang Hak Desain Industri, kecuali jika terbukti sebaliknya". Dan Pasal 3 UU No. 15 Tahun 2001 tentang Merek yang menyatakan bahwa "Hak atas Merek adalah hak eksklusif yang diberikan oleh Negara kepada Pemilik Merek yang terdaftar dalam Daftar Umum Merek untuk jangka waktu tertentu dengan menggunakan sendiri Merek tersebut atau memberikan izin kepada pihak lain untuk menggunakannya". Jelas 
dapat disimpulkan bahwa sistem pendaftaran yang dianut oleh UU No. 31 Tahun 2000 tentang Desain Industri dan UU No.15 Tahun 2001 tentang Merek adalah bersifat konstitutif.

Perlindungan hukum terhadap Hak Desain Industri diberikan untuk jangka waktu adalah 10 (sepuluh) tahun terhitung sejak tanggal penerimaan (Pasal 5 UU No. 31 Tahun 2000 tentang Desain Industri). Sedangkan merek terdaftar mendapatkan perlindungan hukum untuk jangka waktu 10 (sepuluh) tahun sejak tanggal penerimaan dan jangka waktu perlindungan ini dapat diperpanjang kembali (Pasal 28 UU No. 15 Tahun 2001 tentang Merek). Bedanya dengan Merek, perlindungan hukum terhadap Hak Desain Industri tidak dapat diperpanjang kembali. Selanjutnya Kantor Pendaftaran akan menerbitkan Sertifikat Pendaftaran Hak Desain Industri dan Sertifikat Pendaftaran Merek sebagai bukti tertulis bahwa Hak Desain Industri dan Mereknya tersebut resmi sudah terdaftar, dan sertifikat tersebut akan diberikan kepada Pemegang Hak
Desain Industri dan Pemilik Merek terdaftar.

Pasal 2, 3, dan 4 jo. Pasal 10 sampai dengan Pasal 30 UU No. 31 Tahun 2000 tentang Desain Industri dan Pasal 4, 5, dan 6 jo. Pasal 7 sampai dengan Pasal 27 UU No. 15 Tahun 2001 tentang Merek mengatur secara tegas mengenai mekanisme pendaftaran dan persyaratan yang harus dipenuhi agar suatu desain industri dan merek dapat didaftarkan, yang meliputi persyaratan substantive (materiil) dan administrtif (formal).

Syarat substantif bagi desain industri, yaitu bahwa suatu desain industri harus memenuhi unsur novelty (kebaharuan), industrial applicability (bernilai praktis dan dapat diterapkan/diproduksi dalam industi), tidak termasuk dalam daftar pengecualian (bertentangan dengan peraturan yang berlaku, ketertiban umum, agama atau kesusilaan), dan apakah Pendesain atau orang yang menerima lebih lanjut Hak Desain tersebut berhak atu tidak atas desain tersebut. Sedangkan syarat substantif bagi merek, yaitu bahwa suatu tanda yang akan digunakan sebagai merek 
harus memenuhi unsur pembeda/daya pembeda (capable of distinguishing), tidak bertentangan dengan kesusilaan dan ketertiban umum (morality and public order), bukan menjadi milik umum (not becoming public property), bukan keterangan mengenai barang/jasa yang dimintakan pendaftaran, tidak mempunyai persamaan pada pokoknya atau keseluruhannya dengan merek milik orang lain yang sudah terdaftar, bukan peniruan atau menyerupai nama/singkatan nama, bendera, lambang/simbol/emblem dari Negara atau lembaga nasional maupun internasional kecuali atas persetujuan, bukan peniruan atau menyerupai tanda/cap/stempel resmi yang digunakan Negara atau lembaga pemerintah kecuali atas persetujuan, bukan peniruan atau menyerupai nama orang terkenal, foto, atau nama badan hukum yang dimiliki orang lain kecuali atas persetujuan. Adapun syarat administratif, baik bagi desain industri dan merek, yaitu persyaratan dalam pengajuan permohonan pendaftaran, kelengkapan dokumen administratif yang harus dipenuhi oleh pihak pemohon, sampai dengan pembayaran biaya administratif pendaftaran.

\section{Model ideal perlindungan pemegang hak desain industri bagi UMKM di Indonesia}

Secara konseptual, inti dari arti dari penegakan hukum terletak pada kegiatan menyerasikan hubungan nilai-nilai yang terjabarkan di dalam kaidah-kaidah secara mantap guna mengejawantahkannya dengan sikap tindak sebagai rangkaian penjabaran nilai tahap akhir, untuk menciptakan, memelihara dan mempertahankan kedamaian pergaulan hidup. Konsepsi yang mempunyai dasar filosofis tersebut, memerlukan penjelasan lebih lanjut sehingga akan tampak lebih kongkret, seperti pernyataan berikut: ${ }^{18}$

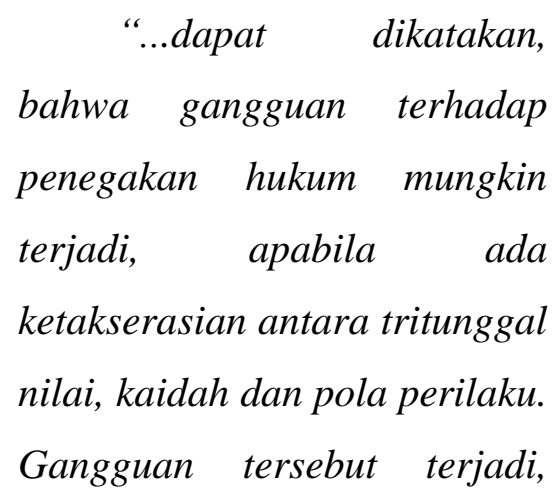

18 Ansori Sinungan, Perlindungan Desain Industri; Tantangan dan Hambatan Dalam Praktiknya di Indonesia, (Bandung: PT Alumni Bandung, 2011), hlm. 484-489. 
apabila terjadi ketakserasian antara nilai-nilai yang berpasangan, yang menjelma di dalam kaidah-kaidah yang bersimpang siur, dan pola perilaku tidak terarah yang mengganggu kedamaian pergaulan hidup., 19

Tentang jumlah UndangUndang yang mengatur perlindungan mengenai desain industri, dalam praktiknya dapat diberikan perlindungan terhadap desain industri dengan menggunakan UU Hak Cipta secara umum dan perlindungan secara khusus menggunakan Undang-Undang Desain Industri.

Perlindungan melalui sistem pendekatan hak cipta didasarkan atas persyaratan penerapan ciptaan langsung pada karya, baik dua dimensi maupun tiga dimensi. Perlindungan hak cipta terhadap desain industri tiga dimensi telah dilakukan secara otomatis tanpa

19 Soerjono Soekanto dalam Ansori Sinungan, Perlindungan Desain Industri; Tangtangan dan Hambatan Dalam Praktiknya di Indonesia, (Bandung: PT Alumni Bandung, 2011), hlm. 489. pendaftaran terhadap berbagai macam barang-barang kerajinan yang memiliki nilai seni (artistic work) maupun barang-barang dari berbagai macam seni rupa itu sendiri. Sesuai dengan sifat dari hak cipta, ciptaan yang merupakan karya terapan (applied work), akan mendapatkan perlindungan secara otomatis begitu ciptaan tersebut diumumkan. Pendaftaran ciptaan yang dilakukan melalui Ditjen HKI, hanya bersifat anggapan hukum dalam arti barang siapa yang mengajukan permohonan pendaftaran, ia dianggap sebagi pencipta atau pemegang hak cipta kecuali dapat dibuktikan sebaliknya. Jadi, walaupun sudah dikeluarkan Undang-Undang khusus yang akan memberikan perlindungan terhadap desain industri (UU Desain Industri), dalam praktiknya, secara tak langsung UU Hak Cipta juga masih tetap memberikan perlindungan terhadap desain industri yang telah diwujudkan dalam bentuk nyata berupa ciptaan terapan (applied works). ${ }^{20}$

20 Ansori Sinungan, Op. Cit, hlm. 486. 


\begin{abstract}
Terkait dengan masalah administrasi pendaftaran desain industri, sistem yang menerapkan kombinasi antara sistem hak cipta (tanpa pemeriksaan) dan sistem paten (melalui pemeriksaan) dalam praktiknya belum dapat berjalan secara efektif. Secara filosofis, apa yang diinginkan oleh pembuat undang-undang adalah cukup ideal. Dengan diterapkannya sistem kombinasi hak cipta dan paten, diharapkan para pendesain dari kelompok UMKM dapat langsung memperoleh perlindungan desain industri tanpa melalui pemeriksaan substantif, kalaupun terjadi pemeriksaan substantif, hal itu disebabkan adanya oposisi karena desain industri yang diajukan pendaftarannya dianggap tidak baru.
\end{abstract}

Akan tetapi, dalam kenyataannya terdapat banyak desain-desain industri yang sebenarnya sudah tidak baru, tetapi didaftarkan, mengingat budaya hukum masyarakat yang belum memahami tujuan yang sebenarnya sistem kombinasi dari perlindungan desain industri tersebut, banyak timbul sengketa-sengketa setelah diterbitkannya sertifikat desain industri. Menurut analisis diatas, penulis berkesimpulan, bahwa untuk model perlindungan desain industri untuk masa depan, pemerintah seharusnya melakukan revisi terhadap sistem yang diterapkan berdasarkan UU Desain Industri yang berlaku perlu segera diprioritaskan guna menghindari lebih banyak permasalahan atau sengketa-sengketa yang terjadi.

Perlunya aturan hukum dalam bentuk Undang-undang yang mengatur mengenai desain industri UMKM dan merek dimaksudkan untuk memberikan perlindungan hukum yang tegas, jelas, dan efektif guna mencegah berbagai bentuk pelanggaran, yang dilakukan oleh orang yang tidak berhak, berupa peniruan dan pemalsuan. Di samping itu juga perlindungan hukum desain industri dan merek ini dimaksudkan untuk menjamin hak-hak serta kewajiban-kewajiban pendesain dan pemilik merek.

Salah satu UMKM yang berkembang pesat adalah UMKM dalam bidang Batik, sebagai produk nasional yang menjadi kebanggaan 
bangsa Indonesia, memiliki beragam desain motif batik yang menjadi ciri khas dari asal daerah yang bersangkutan. Oleh karena desain motif batik dan merek dagang dari produk batik merupakan kekayaan intelektual, maka sudah seharusnya mendapatkan perlindungan hukum. Perlindungan hukum terhadap desain tekstil untuk desain motif batik, akan merangsang aktifitas kreatif pendesain untuk terus menerus berkarya dalam menciptakan desaindesain motif batik yang baru maupun desain-desain baju batik yang baru yang dapat menjadi "trend" dikalangan masyarakat luas. ${ }^{21}$ Sedangkan perlindungan hukum terhadap merek dagang produk batik akan memberikan kepastian hukum bagi perusahaan sebagai pemilik merek dalam penggunaan merek dagangnya untuk produk batik yang diproduksi maupun dipasarkan ke masyarakat. Dengan adanya kepastian hukum ini, maka mencegah orang lain yang tidak

21 Ashibly, Pengelolaan Hak Kekayaan Intelektual Bagi Pencipta Dan Pemilik Merek Sebagai Upaya Memberikan Perlindungan Hukum, Jurnal Jendela Hukum dan Keadilan Volume 4 Nomor 1 Juni 2017, hlm. 4 berhak untuk memakai merek yang sama pada pokoknya atau pada keseluruhan dengan merek dagang produk batik dari si pemilik merek yang sah. Selain itu juga mencegah orang lain yang tidak berhak untuk memakai/menggunakan/membuat/me njual desain orang lain yang bukan miliknya. $^{22}$

Pasal 6, 7, dan 8 UU No. 31/2000 tentang Desain Industri mengatur secara tegas mengenai subjek desain industri. Pasal 6 ayat (1) menyatakan bahwa "yang berhak memperoleh hak desain industri adalah Pendesain atau yang menerima hak tersebut dari Pendesain". Sedangkan ayat (2) nya menyatakan bahwa "dalam hal Pendesain terdiri atas beberapa orang secara bersama maka hak desain industri diberikan kepada mereka secara bersama, kecuali diperjanjikan lain”. Lebih jauh Pasal 7 ayat (1) UU No. 31/2000 tentang Desain Industri menyatakan bahwa "jika suatu desain industri dibuat dalam hubungan dinas dengan pihak lain

22 Bismar Nasution, Pengaruh Globalisasi Ekonomi Pada Hukum Indonesia, Majalah Hukum Medan, Fakultas Hukum USU, Vol.6, 2003, hlm. 6 
dalam lingkungan pekerjaannya, yang menjadi Pemegang Hak Desain Industri adalah pihak yang untuk dan/atau dalam dinasnya desain industri itu dikerjakan, ${ }^{23}$ kecuali ada perjanjian lain antara kedua pihak dengan tidak mengurangi hak Pendesain apabila penggunaan desain industri diperluas sampai ke luar hubungan dinas". Ayat (2) menyatakan bahwa " ketentuanketentuan sebagaimana dimaksud dalam ayat (1) berlaku pula bagi desain industri yang dibuat orang lain berdasarkan pesanan yang dilakukan dalam hubungan dinas". Dan ayat (3) nya menyatakan bahwa “jika suatu desain industri dibuat dalam hubungan kerja atas berdasarkan pesanan, orang yang membuat desain industri itu dianggap sebagai Pendesain dan Pemegang Hak Desain Industri, kecuali jika diperjanjikan lain antara kedua pihak". Berdasarkan ketentuan Pasal 8 UU No. 31/2000 tentang Desain Industri, Pendesain tetap mempunyai hak untuk tetap dicantumkan

23 Sukarmi, Perlindungan Desain Industri Bagi Umkm Yang Berkeadilan Sosial, Jurnal Pembaharuan Hukum Volume III No. 1 Januari - April 2016, hlm. 8 namanya dalam Sertifikat Desain Industri, Daftar Umum Desain Industri dan Berita Resmi Industri. ${ }^{24}$ Pendesain dapat diartikan sebagai subjek hukum, baik secara perorangan atau dalam ikatan kelompok, yang menghasilkan/melahirkan suatu karya desain yang bersifat khas dan dijadikan suatu "pattern" dalam kegiatan produksi pada dunia industri. Sedangkan Pemegang Hak Desain adalah Pendesain sebagai Pemilik Desain atau orang yang menerima hak atas desain tersebut dari Pendesain, atau orang lain yang menerima lebih lanjut hak termaksud dari orang-orang yang terlebih dahulu. $^{25}$

Dalam kondisi yang umum, Pendesain melakukan kegiatannya secara mandiri tidak terikat dalam hubungan hukum dengan pihak lain, misalnya dalam ikatan kerja atau

\footnotetext{
${ }^{24}$ Muchtar A H Labetubun, Aspek Hukum Perlindungan Desain Industrikerajinan Kerang Mutiara Dalam Pemberdayaan Usaha Kecil Di Kota Ambon, Jurnal Sasi Vol. 17 No. 2 Bulan April - Juni 2011, hlm. 4

${ }^{25}$ Sulasn, Penerapan Kekayaan Intelektual (KI) Terhadap UMKM sebagai Upaya Mewujudkan Persaingan Bisnis Berkeadilan , Jurnal Ilmu Hukum, Vol. 2 No. 2. Desember 2018, hlm. 8
} 
perburuhan, maka secara mudah dapat ditentukan bahwa pihak yang menjadi Pemegang Hak dan sekaligus Pemilik Hak atas Desain adalah Pendesain itu Sendiri. Namun dalam hal Pendesain menjalankan kegiatannya terikat dalam hubungan hukum dengan pihak lain, terdapat ketentuan tertentu mengenai subjek hukum desain industri sebagai berikut $:^{26}$

d. Jika suatu desain dibuat dalam hubungan dinas atau hubungan kerja, pihak yang berhak memperoleh hak desain adalah pihak yang memberikan pekerjaan tersebut, kecuali ada perjanjian lain antara pendesain dengan pihak tempatnya bekerja. Meskipun secara prinsip yang berhak memiliki hak desain itu adalah pihak yang memberikan pekerjaan, pendesain berhak memperoleh imbalan yang

${ }^{26}$ Putra, Fajar Nurcahya Dwi, Perlindungan Hukum bagi Pemegang Hak atas Merek terhadap Perbuatan Pelanggaran Merek, ( Jurnal Ilmu Hukum, Edisi Januari-Juni 2014), hlm. 7 layak dengan memperhatikan manfaat ekonomi yang dapat diperoleh dari hasil desain tersebut;

e. Jika suatu desain dibuat berdasarkan pesanan, pihak yang membuat desain itu sebagai pendesainnya dan sebaliknya pemilik desain itu sebagai pemesannya, kecuali apabila diperjanjikan lain antara kedua pihak tersebut;

f. Desain yang dihasilkan baik oleh karyawan maupun pekerja yang menggunakan data dan sarana yang tersedia dalam pekerjaannya, pemiliki desain tersebut adalah pihak tempat karyawan/pekerja tersebut bekerja, sekalipun perjanjian kerja itu mengharuskannya untuk menghasilkan desain.

Dengan demikian, meskipun pendesain tidak mempunyai hak atas desain tersebut, pendesain tetap berhak memperoleh kompensasi karena adanya nilai ekonomi yang diperoleh dari desain tersebut.

Dengan demikian, Pemegang

Hak Desain Indusrtri adalah 
Pendesain, atau Penerima hak dari Pendesain karena pewarisan atau pengalihan atau sebab-sebab lain yang dibenarkan Undang-undang, atau Pemberi kerja dalam hubungan dinas, atau Pembuat sebagai Pendesain dalam hubungan kerja, yang namanya tercatat dalam Daftar Umum Desain Industri. Jadi dasar yuridis untuk mengetahui siapa Pemegang Hak Desain Industri yang sah adalah Daftar Umum Desain Industri, dimana namanya terdaftar dan telah diumumkan secara resmi dalam Berita Resmi Desain Industri.

Oleh karena cakupan desain industri sangat luas serta keterkaitannya dengan disiplin yang lain, maka ada beberapa pihak yang terlibat dalam konsep desain industri, yaitu Desainer sebagai orang yang merancang, Manufaktur yang membuat produk, Pemakai produk (konsumen/masyarakat), Lembaga Swadaya Masyarakat terutama di bidang konsumen dan lingkungan hidup, dan Pemerintah.

Dalam bidang merek, pemilik merek adalah seseorang, beberapa orang secara bersama-sama atau badan hukum yang telah menciptakan suatu tanda yang digunakan sebagai merek untuk produk yang mereka produksi dan/atau perdagangkan, yang mana merek tersebut sudah terdaftar dalam Daftar Umum Merek. Jadi Pemegang Hak atas Merek adalah Pemilik Merek itu sendiri atau orang lain yang mendapat hak atas merek dari si Pemilik Merek berdasarkan perjanjian (lisensi). ${ }^{27}$

Agar desain industri dan merek dagang, dalam hal ini desain tekstil untuk desain motif batik dan merek dagang untuk produk Batik, dapat dilindungi hukum adalah dengan cara pendaftaran. Pendaftaran desain industri (desain tekstil untuk desain motif batik) menimbulkan hak eksklusif, yaitu hak khusus yang hanya diberikan oleh Negara untuk jangka waktu tertentu kepada Pemegang Hak Desain Industri untuk melaksanakan sendiri hak desain

27 UU No.15/2001 tentang Merek tidak mengatur secara tegas pengertian Pemilik Merek. Namun secara implisit hal tersebut dalam dilihat dari isi Pasal 3 UU No.15/2001 tentang Merek beserta Penjelasannya. Pasal 3 menyatakan bahwa "Hak atas Merek adalah hak eksklusif yang diberikan oleh Negara kepada Pemilik Merek yang terdaftar dalam Daftar Umum Merek untuk jangka waktu tertentu dengan menggunakan sendiri Merek tersebut atau memberikan izin kepada pihak lain untuk menggunakannya." 
industri yang dimilikinya, atau memberikan persetujuan/izin kepada pihak lain untuk melaksanakan haknya atas desain tersebut. Dengan demikian orang lain yang tidak berhak dilarang menggunakan/membuat/memakai/me njual desain industri tersebut tanpa persetujuan dari Pemegang Hak Desain Industri ${ }^{28}$. Pemegang Hak Desain Industri memberikan persetujuan (izin) kepada pihak lain untuk melaksanakan (menggunakan) haknya atas desain tersebut dapat melalui pewarisan, hibah, wasiat, perjanjian tertulis, atau sebab-sebab lain yang dibenarkan oleh Undangundang $^{29}$. Hal yang sama berlaku juga untuk merek dagang produk batik. Pendaftaran merek (merek dagang produk batik) menimbulkan hak eksklusif, yaitu hak khusus yang hanya diberikan oleh Negara kepada bagi Pemilik Merek yang terdaftar dalam Daftar Umum Merek untuk jangka waktu tertentu menggunakan sendiri merek tersebut atau memberikan persetujuan (izin)

${ }^{28}$ Pasal 9 ayat (1) UU No. 31 Tahun 2001 tentang Desain Industri.

${ }^{29}$ Pasal 31 UU No. 31 Tahun 2000 tentang Desain Industri. kepada pihak lain untuk menggunakannya ${ }^{30}$. Pemilik Merek yang terdaftar dalam Daftar Umum Merek dapat memberikan persetujuan (izin) kepada pihak lain untuk menggunakan mereknya melalui pewarisan, hibah, wasiat, perjanjian tertulis, atau sebab-sebab lain yang dibenarkan oleh Undangundang. ${ }^{31}$

\section{DAFTAR PUSTAKA}

\section{$\underline{\text { BUKU }}$}

Abdulkadir Muhammad, Kajian Hukum Ekonomi Hak Kekayaan Intelektual, PT Citra Aditya Bakti, Bandung, 2001

Adrian Sutedi, Hak Atas Kekayaan Intelektual, Sinar Grafika, Bandung, 2009

Ansori Sinungan, Perlindungan Desain Industri; Tantangan dan Hambatan Dalam Praktiknya di Indonesia, PT Alumni Bandung, Bandung, 2011

\footnotetext{
${ }^{30}$ Pasal 3 UU No. 15 Tahun 2001 tentang Merek.

${ }^{31}$ Pasal 40 UU No. 15 Tahun 2001 tentang Merek.
} 
Muhammad Djumhana dan R.

Djubaedillah, Hak Milik Intelektual (Sejarah, teori dan prakteknya di Indonesia), Edisi Revisi, Cetakan Ketiga PT. Cipta Aditya Bakti, Bandung, 2003 , Aspek-Aspek Hukum

Desain Industri di Indonesia, PT. Citra Aditya Bakti, Bandung, 1999 perkembangan Doktrin dan Teori Perlindungan Hak Kekayaan Intelektual, PT. Citra Aditya Bkti, Bandung, 2006

Ranti Fauza Mayana, Pelindungan Desain Industri di Indonesia dalam era Perdagangan Bebas, Grasindo, Jakarta, 2004 Yustiono, Paradigma Desain Indonesia, Paradigma Desain Indonesia, ed. Agus Sachari, Rajawali, Jakarta, 1986

\section{JURNAL}

Ashibly, Pengelolaan Hak Kekayaan Intelektual Bagi Pencipta Dan Pemilik Merek Sebagai Upaya Memberikan Perlindungan
Hukum, Jurnal Jendela Hukum dan Keadilan Volume 4 Nomor 1 Juni 2017

Bismar Nasution, Pengaruh Globalisasi Ekonomi Pada Hukum Indonesia, Majalah Hukum Medan, Fakultas Hukum USU, Vol.6, 2003

Muchtar A H Labetubun, Aspek Hukum Perlindungan Desain Industrikerajinan Kerang Mutiara Dalam Pemberdayaan Usaha Kecil Di Kota Ambon, Jurnal Sasi Vol. 17 No. 2 Bulan April - Juni 2011

O. M. Febriani and A. S. Putra, "Sistem Informasi Monitoring Inventori Barang Pada Balai Riset Standardisasi Industri Bandar Lampung," J. Inform., vol. 13 , no. 12014

Putra, Fajar Nurcahya Dwi, Perlindungan Hukum bagi Pemegang Hak atas Merek terhadap Perbuatan Pelanggaran Merek, Jurnal Ilmu Hukum, Edisi JanuariJuni 2014 
Afif Nashiruddin, Kepastian Hukum Perlindungan Pemegang Hak Desain Industri Bagi UMKM Di...

Sukarmi, Perlindungan Desain

Industri Bagi Umkm Yang

Berkeadilan Sosial , Jurnal

Pembaharuan Hukum Volume

III No. 1 Januari - April 2016

Sulasn, Penerapan Kekayaan

Intelektual (KI) Terhadap

UMKM sebagai Upaya

Mewujudkan Persaingan

Bisnis Berkeadilan , Jurnal

Ilmu Hukum, Vol. 2 No. 2.

Desember 2018

\section{Undang-undang}

Undang-undang Nomor 31 Tahun 2001

tentang Desain Industri.

Undang-undang Nomor 15 Tahun 2001

tentang Merk 
Afif Nashiruddin, Kepastian Hukum Perlindungan Pemegang Hak Desain Industri Bagi UMKM Di... 